\title{
Kinetic analysis on physical segments of forward breakfall of the martial arts
}

\author{
Oh Cheong Hwan, Shin Eui Su*, Hong Soo Young, Bea Jae Hee \\ From 4th Congress of the International Foot and Ankle Biomechanics (i-FAB) Community \\ Busan, Korea. 8-11 April 2014
}

The purpose of this study was to provide basic quantitative data to minimize the injury occurring during forward breakfall by the comparative analysis of biomechanical factors through 3D motion analysis, analysis of ground reaction force, and EMG analysis of the forward breakfall of the martial arts targeting 10 skilled and 10 unskilled subjects.

In this study, three-dimensional motion analysis, the nine high-speed camera (Motionmaster 100, KOR) was used, the desired total floor reaction force device (ATMI, USA) 2 units was measured using an impact force. And the floor reaction force and three-dimensional motion analysis program was used for the Kwon3dXP. Group differences for verification and program SPSS 21.0 was used. The following are the findings.

First, the total time taken for forward breakfall of the martial arts showed $1.53 \pm 0.04 \mathrm{~s}$ for skilled, and $1.41 \pm 0.06 \mathrm{~s}$ for unskilled subjects $(p<.01)$.

Second, during forward breakfall of the martial arts, the skilled subjects came up with significantly faster impact velocity in the primary point of impact (E2) $(p<.001)$, but the unskilled subjects showed significantly faster impact velocity in the secondary point of impact (E3) $(p<.001)$.

Third, the forward breakfall of the martial arts did not show any difference between left and right side in the reaction force, but unskilled subjects proved a significantly greater forward and backward reaction force in the secondary point of impact(E3) both right and left sides(right: $p<.01$, left: $p<.001)$. The skilled subjects showed a significantly greater vertical reaction force in the primary point of impact(E2) (right: $p<.001$, left: $p<.001)$, and unskilled subjects showed a larger vertical reaction force in the secondary point of impact (E3), respectively(right: $p<.01$, left: $p<.05)$.

\footnotetext{
* Correspondence: sin76@cnu.ac.kr

Physical Education, Chungnam National Univ., Gung-dong, Yuseong-gu,
} Daejeon, 305-764, Korea

(C) 2014 Hwan et al; licensee BioMed Central Ltd. This is an Open Access article distributed under the terms of the Creative Commons Attribution License (http://creativecommons.org/licenses/by/4.0), which permits unrestricted use, distribution, and reproduction in any medium, provided the original work is properly cited. The Creative Commons Public Domain Dedication waiver (http:// creativecommons.org/publicdomain/zero/1.0/) applies to the data made available in this article, unless otherwise stated. and take full advantage of:

- Convenient online submission

- Thorough peer review

- No space constraints or color figure charges

- Immediate publication on acceptance

- Inclusion in PubMed, CAS, Scopus and Google Scholar

- Research which is freely available for redistribution Submit your manuscript at
www.biomedcentral.com/submit C BioMed Central 